\title{
ONTOLOGY-BASED DATA MAPPING TO SUPPORT PLANNING IN HISTORICAL URBAN CENTRES
}

\author{
E. Colucci ${ }^{1}$, M. Kokla ${ }^{2}$, F. Noardo ${ }^{3}$ \\ ${ }^{1}$ Department of Environmental, Land and Infrastructure Engineering (DIATI) - Politecnico di Torino \\ C.so Duca degli Abruzzi 24, 10129, Torino (Italy) (elisabetta.colucci@polito.it) \\ ${ }^{2}$ School of Rural and Surveying Engineering, National Technical University of Athens, Athens (Greece) \\ (mkokla@survey.ntua.gr) \\ ${ }^{3}$ 3D geoinformation group - Delft University of Technology, Delft (The Netherlands) \\ (f.noardo@tudelft.nl)
}

\section{Commission IV, ISPRS WG IV/2}

KEYWORDS: Semantic Definition, Urban Mapping, Spatial Ontology, Historical Urban Centres, Villages, Historical Core Regulation, CityGML, Spatial Datasets

\begin{abstract}
:
Because of the need for new sustainable future alternatives, the re-inhabitation of rural areas, hinterlands, small historical urban centres and villages has become a unique real opportunity. Therefore, it is necessary to define and adopt new sustainable urban planning and building permits to follow this path. These processes involve both various actors and disciplines and a variety of spatial and semantic data. For this reason, the present research aims at providing a methodology to build the necessary spatial documentation of historical centres and villages by adopting an ontology-based workflow. Existing ontologies and conceptualisations have been considered together with classes and rules from city historical core regulations. A case study has been selected considering its available spatial datasets and national data models. The bottom-up approach here adopted aims at validating and enriching a reference ontology previously developed in the domain of historical centre by adding new concepts and relations from selected regulation plans and other existing ontologies and data models. Finally, the obtained ontology is also populated with instances of concepts and relations.
\end{abstract}

\section{INTRODUCTION}

Due to the need for sustainability and environment - friendly choices, as well as decentralisation - even more recently outlined by the pandemic and the climate change effects on cities (Istituto di Architettura Montana, 2020; Mercalli, 2020) - the restoration, revitalisation and the re-inhabitation of marginal urban or rural areas and small historical centres and villages are regarded as a new real opportunity and a necessity. Besides, this meets the safeguarding need of such centres from a cultural point of view. In this scenario, urban planning and transformation regulated by building permit processes are incredibly relevant. These processes require diverse information as a reference and could be effectively supported by the digitalisation and efficient information representation, including semantic, spatial and temporal aspects.

However, such historical urban centres are often little documented with the richness and detail necessary to manage complex renovation processes and at the same time respect their history, culture, morphology and possible additional constraints due to their specific nature. The necessary knowledge often exists, but it is distributed across several heterogeneous sources (e.g., maps, geoportals, Spatial Data Infrastructures, online resources, descriptive documents, etc.) maintained by different organisations

In this context, geographical ontologies and linked data technologies can help retrieve the necessary knowledge from many sources.

An ontology is a "formal, explicit specification of a shared conceptualisation" (Borst, 1997, p. 199; Gruber, 1993; Studer et al., 1998); a spatial or geographic ontology defines the

\footnotetext{
${ }^{1} \mathrm{http} / / / \mathrm{www}$. cidoc-crm.org/Resources/crm-core

${ }^{2} \mathrm{http}: / /$ wit.istc.cnr.it/arco

${ }^{3} \mathrm{https} / / /$ dati.beniculturali.it/cultural-ON/ENG.html

${ }^{4}$ https://www.getty.edu/research/tools/vocabularies/aat/
}

concepts and relations for spatial applications (Fonseca et al., 2006; Laurini \& Kazar, 2016; Tomai \& Kavouras, 2004). Linked data (Bizer et al., 2011) could be helpful to publish and connect data (such as spatial ones) on the web, adding their semantic information (Hart \& Dolbear, 2013). Linked data allow connecting the different necessary datasets to represent historical urban centres by means of semantic links (Bucher et al., 2020), within a unique structure, with the aim to share a common knowledge among different use cases and actors.

Different vocabularies and ontologies in the domain of cultural heritage (CIDOC-CRM ${ }^{1}, \mathrm{ARCO}^{2}$, CulturalON ${ }^{3}$, Getty AAT Art and Architecture Vocabulary $\left.{ }^{4}, \ldots\right)$ and geographic information (GeoSPARQL ${ }^{5}$, Geonames, Cidoc-CRMgeo ${ }^{6} \ldots$ ) have already been developed. Some attempts to connect datasets with linked data (such as the BAG - Key Register of Addresses and Buildings glossary set according to linked data technologies ${ }^{7}$ ) have been made. Moreover, some research attempts to semantically define through ontology historical centres and city' core (Colucci et al., 2021; Fiorani, 2019; Kokla et al., 2019).

Despite these efforts, none of these studies can fully spatial describe the knowledge related to historical centres and villages' semantics.

For this purpose, a $\mathrm{PhD}$ research in progress focuses on developing an application ontology in the domain of minor and abandoned historical centres, villages and hamlets (Colucci, 2021). Within this work, different existing conceptualisations, standards, and ontologies (such as conceptualisations and definitions of historical centres, the CIDOC CRM ontologies, GEOSPARQL, Getty AAT vocabulary and CityGML) useful to spatially represent and document historical centres have

\footnotetext{
${ }^{5} \mathrm{https}: / /$ www.ogc.org/standards/geosparql

${ }^{6} \mathrm{http}: / /$ www.cidoc-crm.org/crmgeo/home-5

${ }^{7}$ https://bag.basisregistraties.overheid.nl/restful-api\#
} 
been integrated, following a top-down approach. Starting from this ontology as a reference, the present research implements an ontology enrichment and population process. Ontology enrichment is used to extend the reference ontology with new concepts and relations, whereas ontology population is used to add new concept and relation instances (Petasis et al., 2011).

The ontology-based enrichment and population approach is based on data models of national maps combined with further semantic information derived from official documents that describe; further essential aspects regarding the historical value and character of the village, such as the external appearance of existing buildings and the urban spatial structure. Zoning plan, policy framework and regulations for its protection are mapped to the ontology for building information. For this purpose, a proper case study of a village has been selected $(\S 2)$. Structured data, stored in CityGML ${ }^{8}$ format and standards, have been mapped and harmonised with non-structured data, such as concepts derived from documents and regulations to create a new knowledge base following semantic and ontological rules.

The paper is organised as follows. Section 2 presents the case study. Section 3 reports the methodology's workflow and first results. It is subdivided into different steps (ontology enrichment mapping and population). Finally, Section 4 describes conclusions and future perspectives.

\section{THE CASE STUDY OF SLOTEN}

The selected case study is the village of Sloten in the Netherlands. It was a fortified town, located in the municipality of Gaasterlân-Sleat, in the Dutch province of Fryslân (Friesland). Sloten belongs to the Frisian eleven cities and was an independent municipality until $1984^{9}$. It was enormous strategic importance in earlier times due to its location on a waterway from Sneek to the Zuiderzee.

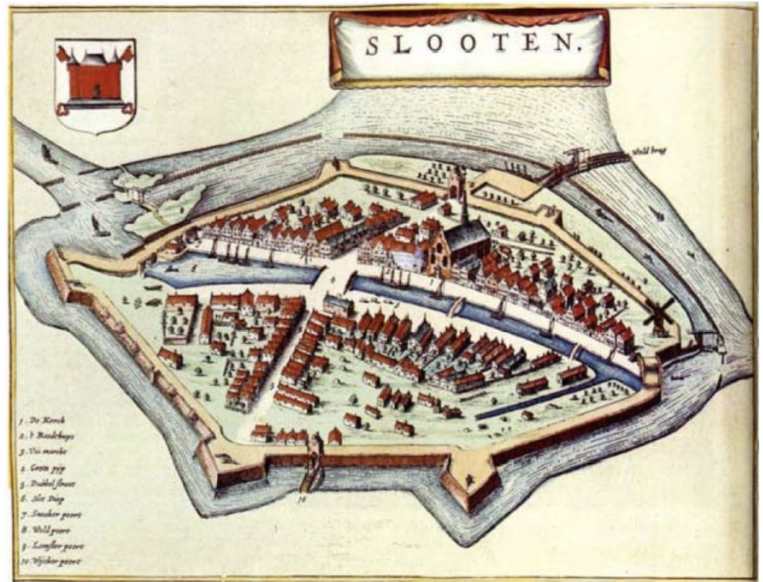

Figure 1. Historical image of the village of Sloten, 1664 (Pouderoyen Compagnons, 2012).

Due to such historical value and the consequent characteristics of the village, reflected in the city regulations, Sloten is selected as an exemplary case study. We can take advantage of the several structured geodatasets $(\S 2.2)$ available (provided by Kadaster, the Dutch National Mapping and Cadastral Agency, and other organisations) plus the information available as descriptions in natural language in the documents

\footnotetext{
${ }^{8} \mathrm{https} / / / \mathrm{www}$. ogc.org/standards/citygml

https://www.friesland.nl/en/discover/eleven-cities-andvillages/sloten
}

2.1aimed at its preservation ( $§ 2.1$, descriptions and rules), which are stored as part of planning regulations.

\subsection{The Zoning Plan for the historical core of Sloten}

The present research analysed the Destination Zoning Plan of the historical core of Sloten, shown in Figure 2, (Pouderoyen Compagnons, 2012).

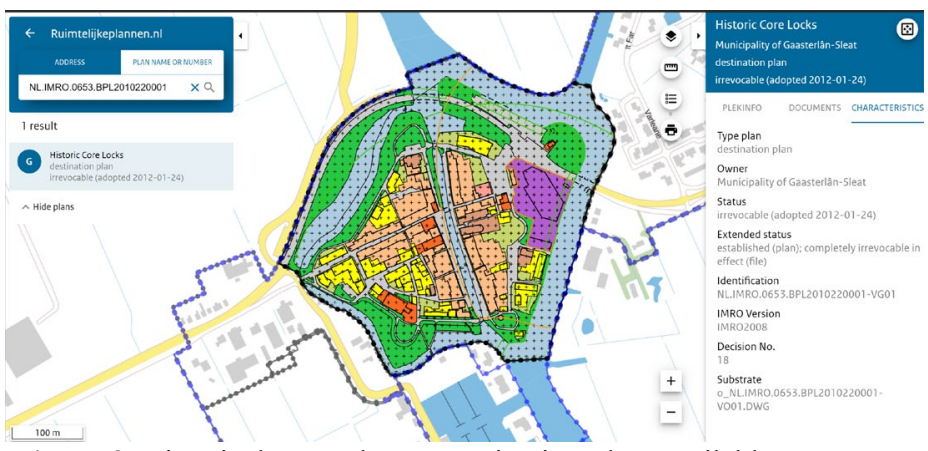

Figure 2. Historical Core Sloten, Destination Plan, available at the national portal viewer for spatial plans Ruimtelijkeplannen.nl.

For the aim of this paper, we selected Article 5, 'Zoning rules to be applied' and Article 20, 'Current State'10.

The destination plans (i.e., Article 5 in our case) refer to city zones represented as geometric objects in the zoning map. They can be downloaded in Geographical Markup Language (GML) format and visualised and queried within Geographical Information System (GIS) tools.

Other regulations refer to different zoning areas, which are often not represented within the same web-GIS (Ruimtelikeplannen.nl) but are reported in further documents. An example related to our case is the sub-areas referred to by Article 20. Such three sub-areas (Figure 3) are intended to cover the parts of the city having standard specific buildings and city features, strictly related to their historical value. Figure 3 .

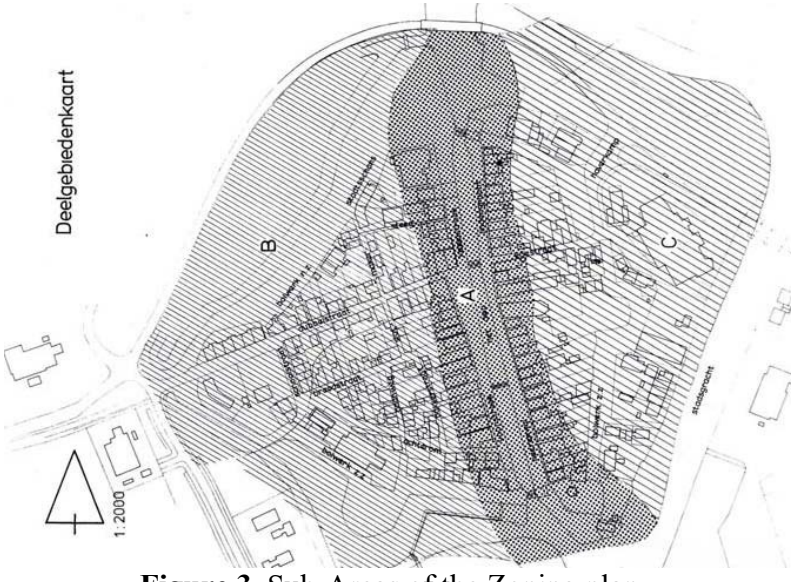

Figure 3. Sub-Areas of the Zoning plan.

\subsection{Available spatial datasets of Sloten}

Several digital maps are available for the selected area as structured spatial datasets Table 1. They were analysed,

\footnotetext{
${ }^{10} \mathrm{https}: / /$ www.ruimtelijkeplannen.nl/documents/NL.IMRO.0 653.BPL2010220001-
}

VG01/r_NL.IMRO.0653.BPL2010220001-VG01.html 
compared, and mapped to the reference ontology to enhance it by integrating with relevant parts of the data schemas.

Table 1. Available datasets of the case study. Highlighted the dataset analysed for the present research.

\begin{tabular}{|c|c|c|c|c|}
\hline Data & Format & Author & $L O D$ & Source \\
\hline $\begin{array}{l}\text { ZONING } \\
\text { PLAN }\end{array}$ & GML & $\begin{array}{l}\text { ruimtelij } \\
\text { keplanne } \\
\text { n }\end{array}$ & LOD0 & $\begin{array}{l}\text { https://www.ruimtelij } \\
\text { keplannen.nl/ }\end{array}$ \\
\hline BGT & CityGML & $\begin{array}{l}\text { Kadaster } \\
\text { PDOK }\end{array}$ & LOD0 & $\begin{array}{c}\text { https://www.pdok.nl/down } \\
\text { loads/- } \\
\text { /article/basisregistratie- } \\
\text { grootschalige-topografie- } \\
\text { bgt- }\end{array}$ \\
\hline BAG & $\begin{array}{l}\text { CityGML } \\
\text { (WFS } \\
\text { service) }\end{array}$ & $\begin{array}{l}\text { Kadaster } \\
\text { PDOK }\end{array}$ & LOD0 & $\begin{array}{c}\text { https://www.pdok.nl/datas } \\
\text { ets }\end{array}$ \\
\hline $\begin{array}{c}\text { 3D BAG } \\
\text { (BAG/PDOK, } \\
\text { BGT, AHN) }\end{array}$ & $\begin{array}{l}\text { CityGML } \\
\text { /IMgeo }\end{array}$ & $\begin{array}{l}\text { Kadaster/T } \\
\text { UD3D }\end{array}$ & LOD 1.3 & $\begin{array}{c}\text { http://3dbag.bk.tudelft.nl/ } \\
\text { downloads }\end{array}$ \\
\hline $\begin{array}{l}\text { PDOK 3D } \\
\text { Basisbestand } \\
\text { Gebouwen }\end{array}$ & $\begin{array}{c}\text { CityJSO } \\
\mathrm{N}\end{array}$ & $\begin{array}{l}\text { Kadaster/T } \\
\text { UD3D } \\
\text { PDOK }\end{array}$ & LOD1-2 & $\begin{array}{c}\text { brt.kadaster.nl/basisvoorzi } \\
\text { ening-3d/ }\end{array}$ \\
\hline OpenStreetMap & OSM & $\begin{array}{c}\text { OSM } \\
\text { community }\end{array}$ & LOD0 & $\begin{array}{c}\text { https://www.openstreetma } \\
\text { p.org/export\#map }=17 / 52 . \\
89449 / 5.64787\end{array}$ \\
\hline
\end{tabular}

\section{METHODOLOGY WORKFLOW}

The methodology, depicted in Figure 4, aims to formalise a knowledge base in the domain of historical centres by extracting concepts and relations from structured and unstructured sources. We consider existing ontologies and data models' classes and definitions to investigate and select relevant information from regulations (such as Sloten's historical core zoning plan).

\section{WORKFLOW of METHODOLOGY}

圈田㢵

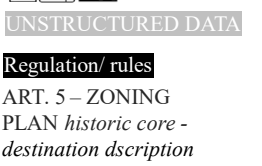

destination dscription

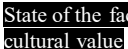

Rules ART. 20 - ZONING PLAN historic core

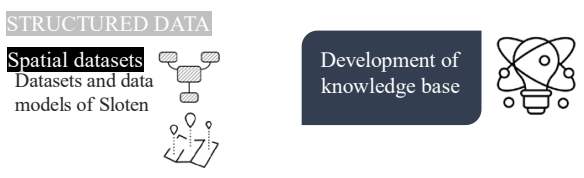

Figure 4. Workflow of the methodology.

The approach follows the workflow steps here summarised and explained in the following subsections.

\section{A. Spatial data mapping and interpretation}

In this step, datasets (GML or CityGML formats) and attributes have been investigated and compared manually by querying them in a GIS environment. The investigation on "how" spatial datasets have been created and populated with attributes will help in linking - through linked data similar information or values to the same semantic concepts defined in the ontology.

This step aims at setting a basis for a possible data conversion from GML to RDF of datasets for future ontology querying and inferencing. This is necessary to connect spatial data and semantic concepts and to create semantic links between the data and the ontology.

\section{B. Ontology enrichment}

a. Selection and analysis of unstructured data: semantic information analysis and formalisation from the documentation available in the regulations related to the historical core zoning plan of the case study (i.e., from Article 5 and Article 20).

$b$. Addition of new concepts and relations to the reference ontology of historical centres from the formalised unstructured knowledge

c. Ontology mapping

mapping concepts and relations of the reference ontology of historical centresto:

- relevant classes of data models of national datasets considered for the case study;

- the useful concepts pointed out according to the regulation's needs and descriptions were selected from the already existing ontologies and added, such as relevant CityGML classes and hierarchies and CICODCRM topological relations.

d. Ontology design

update of the ontology according to the previous mapping. This step has been developed in the Protègè ${ }^{11}$ ontology editor.

\section{Ontology population with instances}

It consists of adding new instances of concepts and relations among them. Instances have been inserted following the regulation rules and the historical village descriptions.

\subsection{Spatial data mapping and interpretation}

In this step, datasets (GML or CityGML formats) and attributes have been inspected and compared manually within GIS environment. This preliminary operation is essential for individuating common or similar entities and attributes among different datasets of the same area or to connect them to same semantic concepts of the ontology. This process is necessary for the future conversion of semantic information and geometries to linked data.

Figure 5 and Table 2 show different or similar values of attributes. In the next phase, this information will be converted to linked data, structured according to the ontology. Figure 6 illustrates the three datasets selected and analysed for the village of Sloten in the open-source software QGIS ${ }^{12}$; for each source the same building or construction area has been queried. On the right in the figure, we notice that different attribute values are referred to corresponding geometries.

\footnotetext{
${ }^{11} \mathrm{https}: / /$ protege.stanford.edu/

$12 \mathrm{https} / / /$ www.qgis.org/it/site/
} 


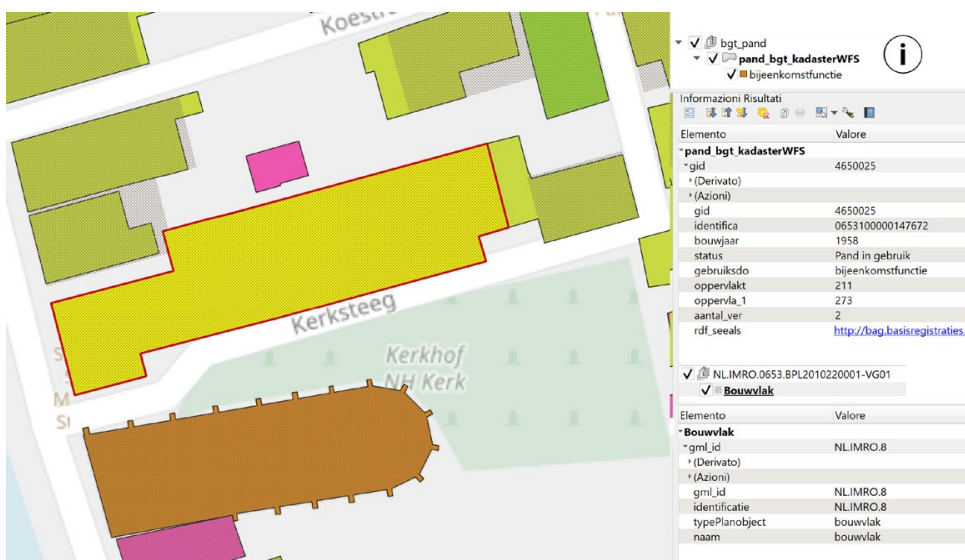

Figure 5. Comparison of attributes of the same building geometries of BGT and BAG datasets.

Table 2. Example of comparison and investigation of the building selected in Figure 5, to check attribute and value similarities (in bold attributes with the same meaning, highlighted in blue the attribute referred to existing linked data).

\begin{tabular}{|c|c|c|c|c|c|}
\hline \multicolumn{2}{|c|}{$\begin{array}{c}\text { Historic Core Locks } \\
\text { Construction area }\end{array}$} & \multicolumn{2}{|c|}{$\begin{array}{c}\text { BGT IMGEO PDOK } \\
\text { building }\end{array}$} & \multicolumn{2}{|c|}{$\begin{array}{c}\text { BAG Kadaster } \\
\text { building (WFS service) } \\
\text { INSPIRE harmonised }\end{array}$} \\
\hline attributes & values & attributes & values & attributes & values \\
\hline identification & NL.IMRO. 10 & gml_id & $\begin{array}{c}\text { gml_id: } \\
\text { bf9c00ceb- } \\
\text { 0e68-6a96- } \\
\text { bb55- } \\
7142 \text { a9ba75 } \\
50\end{array}$ & $\underset{n}{\text { identificatio }}$ & 4650370 \\
\hline name & $\begin{array}{l}\text { Construction } \\
\text { area }\end{array}$ & $\begin{array}{c}\text { creationDat } \\
\mathrm{e}\end{array}$ & $2016-12-07$ & $\begin{array}{c}\text { construction } \\
\text { year }\end{array}$ & 1958 \\
\hline \multirow[t]{6}{*}{$\begin{array}{c}\text { type Plan } \\
\text { object }\end{array}$} & $\begin{array}{l}\text { Construction } \\
\text { area }\end{array}$ & bgt status & existing & status & Building in use \\
\hline & & $\begin{array}{l}\text { relative } \\
\text { Altitude }\end{array}$ & 0 & $\begin{array}{c}\text { purpose of } \\
\text { use }\end{array}$ & meeting function \\
\hline & & $\begin{array}{l}\text { time of } \\
\text { registration }\end{array}$ & $\begin{array}{c}2016-12- \\
07 T 14: 11: 1 \\
4.000\end{array}$ & area_min & 211 \\
\hline & & $\begin{array}{l}\text { LV } \\
\text { publication } \\
\text { date }\end{array}$ & $\begin{array}{c}2017-01- \\
05 T 18: 48: 2 \\
1\end{array}$ & area_max & 273 \\
\hline & & $\begin{array}{c}\text { Namespace } \\
\text { source }\end{array}$ & NL.IMGeo & $\begin{array}{c}\text { number_res } \\
\text { idence } \\
\text { objects }\end{array}$ & 2 \\
\hline & & & & rdf_seealso & $\begin{array}{l}\text { http://bag.basisre } \\
\text { gistraties.overhei } \\
\text { d.nl/bag/id/pand// } \\
06531000001480 \\
72\end{array}$ \\
\hline
\end{tabular}

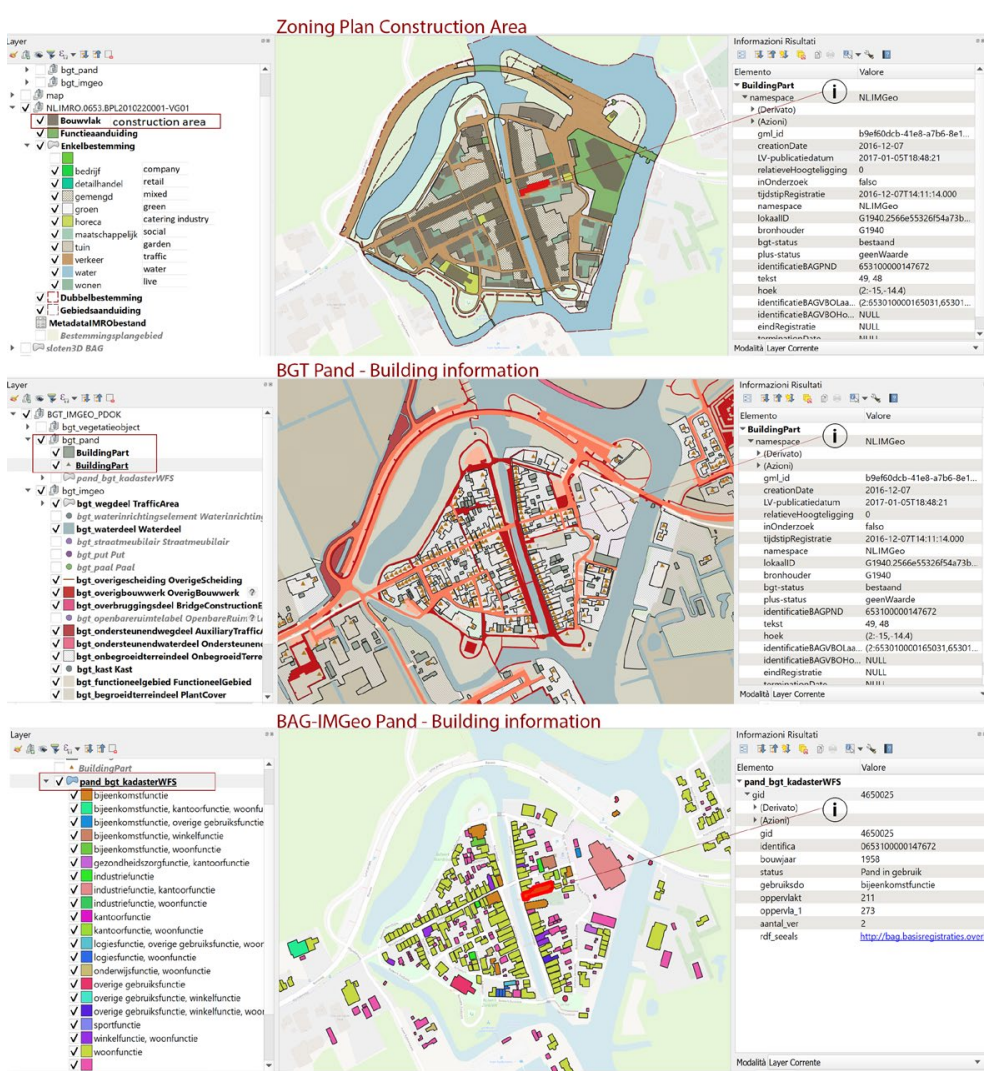

Figure 6. Datasets comparison of BGT, BAG-IMGeo and Zoning Plan entities Building and Construction Area in QGIS.

\subsection{Ontology enrichment}

In the ontology development process, the first phase consists of the specification of spatial concepts and their relations. Ontology enrichment is "the task of extending an existing ontology with additional concepts and semantic relations and placing them at the correct position in the ontology" (Petasis et al., 2011). The first step of the methodological workflow aims to extract concepts and definitions practical to describe historical cores and their urban planning rules.

The Historical core Zoning Plan of Sloten has been analysed following different strategies selecting two different regulation's articles. Art. 5, Rules for Mixed destination, describes the zoning plans and the rules for buildings and city areas; Art. 20 focuses on the current state of the village and its cultural values. This approach was performed using the analysis of articles by manually selecting possible classes and relations through a manual text interpretation and formalisation.

The schemas deriving from the formalisation of the two articles were used according to two different aims:

- Art. 5 would guide the selection of information necessary to check compliance to the rules there stated and represent information requirements;

- Art.20 contributes to build the available information about the village (as well as the other maps and spatial data), part of which will be selected according to Art.5. 
Here is an excerpt of the text with the extracted entities highlighted:
" 5.2 Building rules
5.2.1 Construction of buildings within a construction area
The following rules apply to the construction of buildings within the construction area:
the number of dwellings may not exceed the number existing at the time when the design of this plan was made available for inspection; otherwise, the rules as indicated in 20.2.1 apply.
5.2.2 Construction of buildings and canopies outside a construction area The rules as indicated in 20.2.2 apply to the construction of buildings and roofs outside the construction area.
5.2.3 Construction of structures, not being buildings
For the construction of structures, not being buildings, the rules as indicated in 20.2.3 apply." Art. 5.

A similar procedure for ontology enrichment has been conducted for Art.20, Value and Cultural History. In this case, also instances (reported below) about Sloten village have been considered. It concerns the dual destination throughout the planning area (Area A and Area B), intending to protect the cultural-historical values of the protected cityscape.

"Sub-area $A$.

Building characteristics:

Buildings mainly one storey with roof. Deviations are buildings with a special function

The buildings have an angular design with a simple basic shape,

Parcel width usually allows for a facade layout with a door and 2 to 3 windows, the height of which is greater than the width

The buildings are generally covered with a gable roof, the ridge direction of which is perpendicular to the road,

The facade wall predominantly shows a variety of - sometimes richly decorated - gables. An exception is a hipped roof at the front (usually with one centrally located characteristic dormer window), covered with black glazed tiles;

Facade walls usually consist of clean masonry of yellow or red bricks." Art 20.

The concepts and relations extracted from the regulation are used to enrich the ontology of historical centres. This reference domain spatial ontology was designed following initially a top-down approach based on existing knowledge sources. Linking the semantic representation of the historical centre to the reference ontology will also enable its validation and enrichment with new concepts, relations, attributes, and values.

The Protègè ontology editor has been used for the formalisation and enrichment of the ontology. Table 3 shows some explicative examples of triples developed.

Table 3. Triples of concept implemented during the ontology enrichment.

\begin{tabular}{lll}
\hline Subject & predicate & object \\
\hline BUILDING & consist of & FAÇADE \\
BUILDING & has part & BUILDING ELEMENTS \\
HISTORICAL CENTRE & has & URBAN FEATURES \\
HISTORICAL CENTRE & has-part & PUBLIC SPACE \\
HISTORICAL CENTRE & has & CULTURAL VALUES \\
BUILDING & bounds with & BOUNDARY SURFACE \\
HISTORICAL CENTRE & has part & BUILDING \\
BUILDING & consist of & ROOF \\
\hline
\end{tabular}

\subsection{Ontology mapping}

The reference ontology of historical centres has also been mapped to:

- relevant classes from data models of national datasets, such as the objects house, vegetation and water from the ADE of CityGML implemented for BGT datasets ${ }^{13}$; the RDF classes and attributes of BAG object of the BAG data model $^{14}$ and descriptions from the BAG glossary (e.g., BagHouse is "is a smallest, functional and architecturalstructural independent unit that is directly and permanently connected to the earth and is accessible and lockable"15).

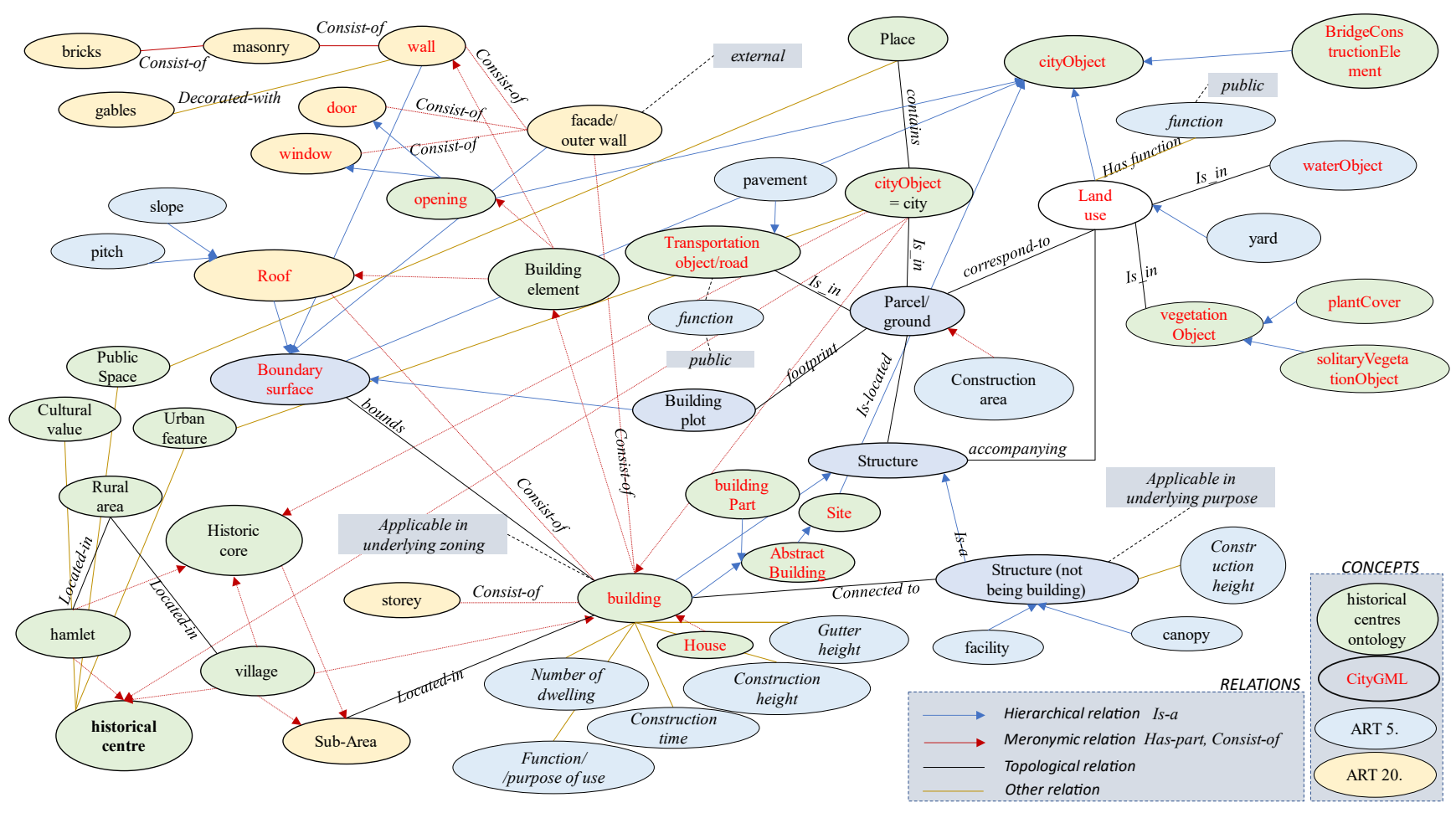

Figure 7. Ontological draft schema of classes and relations from Art.5, Art.20 of Zoning Plan of Sloten, the reference ontology of historical centres and the CityGML

\footnotetext{
${ }_{13} \mathrm{https}: / /$ docs.geostandaarden.nl/imgeo/catalogus/bgt/

${ }^{15}$ https://bag.basisregistraties.overheid.nl/begrippenlijst

${ }^{14} \mathrm{https} / / /$ bag.basisregistraties.overheid.nl/datamodel
} 
- relevant classes from existing ontologies, such as the OWL version of the CityGML v.2.0 data model as developed by the University of Genova ${ }^{16}$ (see concepts selected in Figure 8), as mentioned before, have been identified as CityGML concepts and imported into the ontology structure.

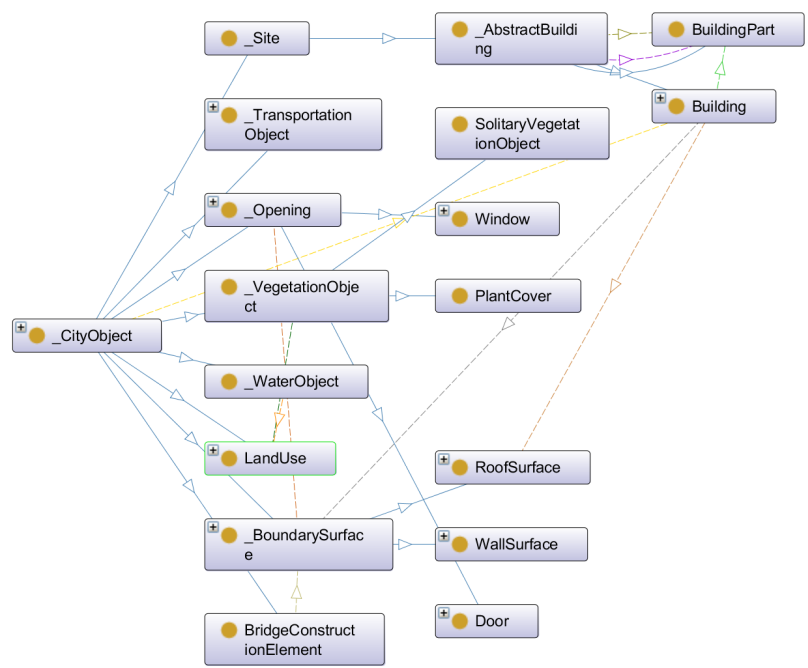

Figure 8. CityGML entities considered for the ontology (OntoGraph viewer, Protègè).

- CIDOC-CRM ontology core relations such as "borders with", "overlaps with" and "contains" (CIDOC $\bar{C}$ RM, 2021) Figure 9.

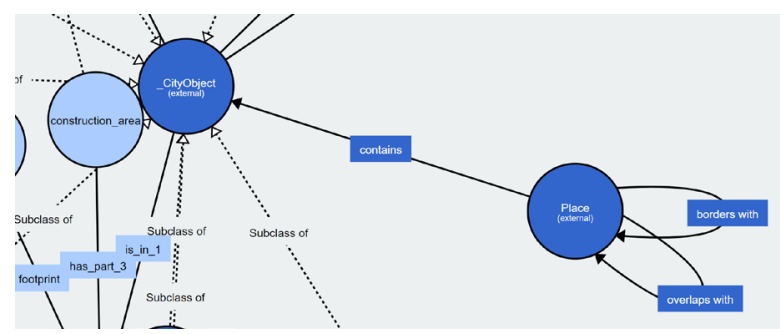

Figure 9. $\overrightarrow{\mathrm{CIDOC}} \mathrm{CRM}$ ontologies relations selected for the present study.

- Moreover, some classes extracted from Art.5 have been compared to concepts of existing ontologies (some examples in Table 4).

Table 4. Comparing concepts among regulations and

\begin{tabular}{|c|c|}
\hline \multicolumn{2}{|c|}{ ontologies. } \\
\hline $\begin{array}{c}\text { Entities form Art.5 - } \\
\text { Rules Mixed }\end{array}$ & $\begin{array}{c}\text { Existing concepts in } \\
\text { ontologies }\end{array}$ \\
\hline Roof & $\begin{array}{c}\text { RoofSurface } \\
\text { (CityGML) }\end{array}$ \\
\hline Building & Building (CityGML) \\
\hline Road & $\begin{array}{c}\text { TransportationObject } \\
\text { (CityGML) }\end{array}$ \\
\hline Building boundary & BoundarySurface \\
\hline Place & Place (CIDOC-CRM) \\
\hline
\end{tabular}

The final output of the mapping is shown in Figure 5. Comparison of attributes of the same building geometries of BGT and BAG datasets.; green classes derive from the historical centres' ontology, blue and yellow from regulations and red text from CityGML ontology and data models.

\footnotetext{
${ }^{16} \mathrm{http}: / /$ cui.unige.ch/isi/onto//citygml2.0.owl
}

\subsection{Ontology population with instances}

Ontology population "is the task of adding new instances of concepts to the ontology" (Kokla et al., 2018; Petasis et al., 2011). Since the aim of the ontology-based methodology is to document historical centres and define information about regulations and building permits of villages to enhance sustainable plans and activities - instances have been added starting from the unstructured knowledge.

Some instances are derived from the description of the historical village of Sloten ${ }^{17}$ (such as "Frisian is the province of Sloten") and others from the text reported in the Art.20. For example, subarea A, B and C are parts of Sloten; the buildings of Area A have "mainly one storey with a gable roof", "facade walls usually consist of clean masonry of yellow or red bricks" and so on. This information represents relevant identity features, which are either not explicit or are totally missing in the spatial datasets and related attributes.

Table 5 reports some instances of concepts and relations added to the ontology.

Table 5. Some instances (from general to specific) added during ontology population.

\begin{tabular}{|c|c|c|c|}
\hline Subject & predicate & object & $\begin{array}{l}\text { Referred to } \\
\text { data-property } \\
\text { or class }\end{array}$ \\
\hline FRISINAN & is the province of & SLOTEN & toponym \\
\hline SLOTEN & is $a$ & VILLAGE & toponym \\
\hline SLOTEN & is $a$ & HISTORICAL CENTRE & toponym \\
\hline SLOTEN & is municipality from & 1984 & toponym \\
\hline SLOTEN & is in the municipality of & GAASTERLÂN-SLEAT & toponym \\
\hline SLOTEN & is in the municipality of & DE FRYSKE MARREN & toponym \\
\hline SLOTEN & has & SUBAREA(s) & Sub-area \\
\hline STOREY & has number & 1 & number \\
\hline SUBAREA A & is part of & SLOTEN & Sub-area \\
\hline SUBAREA B & is part of & SLOTEN & Sub-area \\
\hline SUBAREA C & is part of & SLOTEN & Sub-area \\
\hline BRICK & has colour & YELLOW & colour \\
\hline BRICK & has colour & RED & colour \\
\hline WINDOW & has number & 2 to 3 & number \\
\hline
\end{tabular}

\section{DISCUSSION AND CONCLUSION}

This study presents an ontology-based workflow to semantically define small historical centres and develop a knowledge base to describe village' case studies according to their regulations and zoning plans. The proposed workflow and methodology enable the spatial and semantic documentation of historical centres and villages, formalising information from existing ontologies, conceptualisations and city historical core regulations. This study could support further activities aimed to develop sustainable future options, such as the re-inhabitation of rural areas and hinterlands.

The results of this methodology, an ontology populated with some information from a real case study, describes a first attempt made to define instances of a village to document it and support urban plans concretely. Moreover, this research demonstrates the complexity of application geographical ontologies to link spatial data with semantic descriptions.

Here, the Sloten case has also been studied considering spatial datasets and their data models. The enrichment and population phases were fundamental to defining a representative semantic knowledge within the ontology, which could be connected to existing spatial datasets through linked data. Future work will

${ }^{17}$ https://www.sloten.nl/ 
focus on converting datasets and specifying semantic links between spatial data and the developed ontology.

\section{ACKNOWLEDGMENT}

The work of F. Noardo has received funding from the European Union's Marie Skłodowska-Curie grant agreement No. 707404, Multisource Spatial data Integration for smart City Applications.

\section{REFERENCES}

Bizer, C., Heath, T., \& Berners-Lee, T. (2011). Linked Data: The Story so Far. Semantic Services, Interoperability and Web Applications: Emerging Concepts, 205-227. https://doi.org/10.4018/978-1-60960-593-3.ch008

Borst, W. (1997). Construction of Engineering Ontologies. In Centre of Telematica and Information Technology, .... $\mathrm{http}: / /$ scholar.google.com/scholar?hl=en\&btnG=Search\&q=in title:CONSTRUCTION+OF+ENGINEERING+ONTOLOGI ES\#1

Bucher, B., Folmer, E., Brennan, R., Beek, W., Hbeich, E., Würriehausen, F., Rowland, L., Maturana, R. A., Di Donato, P., Buyle, R., \& Alvarado, E. (2020). Spatial Linked Data in Europe: Report from Spatial Linked Data Session at Knowledge Graph in Action. European Spatial Data Research. http://www.eurosdr.net/sites/default/files/uploaded_files/euro sdr_publication_ndeg_73.pdf

CIDOC CRM. (2021). Definition of the CIDOC Conceptual Reference Model. Chryssoula Bekiari, George Bruseker, Martin Doerr, Christian-Emil Ore, Stephen Stead, Athanasios

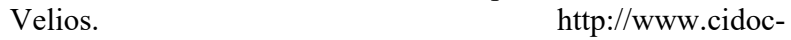
crm.org/sites/default/files/CIDOC\%20CRM_v.7.1\%20\%5B8 \%20March\%202021\%5D.pdf

Colucci, E. (2021). Domain ontology-Small historical centre. Zenodo. https://doi.org/10.5281/zenodo.4707568

Colucci, E., Xing, X., Kokla, M., Mostafavi, M. A., Noardo, F., \& Spanò, A. (2021). Ontology-Based Semantic Conceptualisation of Historical Built Heritage to Generate Parametric Structured Models from Point Clouds. Applied Sciences, 11(6), 2813. https://doi.org/10.3390/app11062813

Fiorani, D. (2019). Il futuro dei centri storici. Digitalizzazione e strategia conservativa, Quasar, Roma 2019. February.

Fonseca, F., Camara, G., \& Miguel, A. (2006). A Framework for Measuring the Interoperability of Geo-Ontologies. Perception, 5868. https://doi.org/10.1207/s15427633scc0604

Gruber, T. R. (1993). A translation approach to portable ontology specifications. In Knowledge Acquisition. https://doi.org/10.1006/knac.1993.1008

Hart, G., \& Dolbear, C. (2013). Linked Data: A Geographic Perspective. Taylor \& Francis. https://library.oapen.org/handle/20.500.12657/41678

Istituto di Architettura Montana. (2020). Per una nuova abitabilità delle Alpi. Architetture per il welfare e la rigenerazione. Archalp N.4, ARCHALP-Rivista internazionale di architettura e paesaggio alpino, 146.
Kokla, M., Mostafavi, M. A., Noardo, F., \& Spanò, A. (2019). Towards building a semantic formalisation of (small) historical centres. ISPRS Annals of the Photogrammetry, Remote Sensing and Spatial Information Sciences, 42(2/W11), 675-683. https://doi.org/10.5194/isprs-Archives-XLII-2W11-675-2019

Laurini, R., \& Kazar, O. (2016). Geographic Ontologies: Survey and Challenges. Journal for Theoretical Cartography, 9, 1-13.

Mercalli, L. (2020). Salire in montagna Prendere quota per sfuggire al riscaldamento globale. Passaggi Einaudi.

Petasis, G., Karkaletsis, V., Paliouras, G., Krithara, A., \& Zavitsanos, E. (2011). Ontology Population and Enrichment: State of the Art. In G. Paliouras, C. D. Spyropoulos, \& G. Tsatsaronis (Eds.), Knowledge-Driven Multimedia Information Extraction and Ontology Evolution (Vol. 6050, pp. 134-166). Springer Berlin Heidelberg. https://doi.org/10.1007/978-3-642-20795-2_6

Pouderoyen Compagnons. (2012). Historic Core of SlotenMunicipality of Gaasterlân-Sleat Destination Plan. ruimtelijkeplannen.nl; document number NL.IMRO.0653.BPL2010220001-VG01.

https://www.ruimtelijkeplannen.nl/documents/NL.IMRO.065 3.BPL2010220001-

VG01/r_NL.IMRO.0653.BPL2010220001-VG01.html

Studer, R., Benjamins, V. R., \& Fensel, D. (1998). Knowledge Engineering: Principles and methods. Data and Knowledge Engineering, 25(1-2), 161-197. https://doi.org/10.1016/S0169-023X(97)00056-6

Tomai, E., \& Kavouras, M. (2004). From 'Onto-GeoNoesis' to 'Onto-Genesis': The design of geographic ontologies. GeoInformatica, $8(3), \quad 285-302$. https://doi.org/10.1023/B:GEIN.0000034822.47211.4a 